\title{
COMPETITION BETWEEN FRESH AND AGED SPERMATOZOA IN FERTILIZING RABBIT EGGS
}

\author{
J. F. ROCHE,* P. J. DZIUK* AND J. R. LODGE \\ Animal Science* and Dairy Science Departments, \\ University of Illinois, Urbana, Illinois, U.S.A.
}

(Received 9th February 1968)

Chance is ordinarily considered to be responsible for determining which spermatozoon fertilizes an egg. Results from experiments on competitive fertilization in hens tend to disprove this concept. When fresh and aged cock spermatozoa competed directly, the eggs were fertilized by the fresh spermatozoa, although the aged spermatozoa alone were capable of fertilization (Warren \& Kilpatrick, 1929). The cocks were mated alternately at intervals of several days, and the last cock always sired the offspring. When spermatozoa from two apparently equally fertile males of different strains of mice or breeds of rabbits were mixed in equal numbers, one male consistently sired a higher proportion of the offspring (Edwards, 1955; Beatty, 1960) adding further doubt to the concept that chance alone determines which spermatozoon fertilizes an egg.

Spermatozoa, whether motile or immotile, and inert particles reached the site of fertilization in cows and sheep equally well within a few minutes of insemination (VanDemark \& Moeller, 1951; Mattner \& Braden, 1963). If aged and fresh spermatozoa were mixed in equal numbers, then both types would presumably be present in equal numbers at the site of fertilization. Differences between aged and fresh spermatozoa in their readiness to fertilize an egg could then be determined from the proportions of offspring produced by each type of spermatozoa.

The following study was conducted to determine the competitive fertilizing ability of a mixture of equal numbers of motile fresh and aged spermatozoa from bucks of two different breeds. Bucks were New Zealand (W) and Dutch Belted (B) and the does were W. Paternity was easily determined by the distinguishing colour of the offspring at birth. Genetic homozygosity and fertility of the bucks were verified by periodic non-competitive matings.

Semen was collected with an artificial vagina and the concentration of spermatozoa determined with a haemocytometer. Motility was determined microscopically. The semen was aged by storage for $24 \mathrm{hr}$ at $5^{\circ} \mathrm{C}$ in a diluent composed of $0.5 \%$ fructose and $2.9 \%$ sodium citrate in distilled water. The percentage motility after storage varied from 30 to 50 compared with 60 to 80 for the fresh spermatozoa. The rate of motility of the spermatozoa after ageing was very low compared with the rate when fresh. Each doe was inseminated with one of the following mixtures, each containing $15 \times 10^{6}$ motile spermatozoa in 0.2 to $0.5 \mathrm{ml}$ of diluent: 


$\begin{array}{rrrr}\text { (i) } & \text { W fresh } & \text { B fresh } & \text { (Wf Bf) } \\ \text { (ii) } & W \text { fresh } & \text { B aged } & \text { (Wf Ba) } \\ \text { (iii) } & W \text { aged } & \text { B fresh } & \text { (Wa Bf) } \\ \text { (iv) } & W \text { aged } & \text { B aged } & \text { (Wa Ba) }\end{array}$

Ovulation was induced by an intravenous injection of 50 i.u. human chorionic gonadotrophin (HCG, Follutein, E. R. Squibb and Sons) at the time of insemination.

The ratio of offspring produced by the Wf Bf mixture was $75 \mathrm{~W}: 25 \mathrm{~B}$ (cf. Table 1). This ratio is significantly different $(P<0.01)$ from a 50:50 ratio. In contrast, the ratio of $42 \mathrm{~W}: 58 \mathrm{~B}$ produced by the Wa $\mathrm{Ba}$ mixture did not differ significantly $(P=0.05)$ from 50:50. Aged spermatozoa (Wa and $\mathrm{Ba}$ ) fertilized eggs with equal readiness which is in contrast to the situation when spermatozoa were fresh (Wf and $\mathrm{Bf}$ ).

TABLE 1

NUMBER AND GOLOUR OF OFFSPRING PRODUCED BY INSEMINATION

\begin{tabular}{c|c|c|cc}
\hline $\begin{array}{c}\text { Spermatozoa } \\
\text { mixture* }\end{array}$ & $\begin{array}{c}\text { Litters } \\
(\text { No. })\end{array}$ & $\begin{array}{c}\text { Litter size } \\
(\text { Mean })\end{array}$ & \multicolumn{2}{|c}{ Colour of offspring } \\
\cline { 3 - 4 } & & & \multicolumn{1}{c}{$W$} & \multicolumn{1}{c}{$B$} \\
\hline Wf Bf & 14 & $7 \cdot 5$ & $80(75 \%)$ & $26(25 \%)$ \\
Wf Ba & 14 & $7 \cdot 7$ & $106(97 \%)$ & $5(3 \%)$ \\
Wa Bf & 11 & $7 \cdot 2$ & $7(9 \%)$ & $72(91 \%)$ \\
Wa Ba & 12 & $6 \cdot 2$ & $31(42 \%)$ & $43(58 \%)$ \\
\hline
\end{tabular}

* No significant difference among groups in litter size or conception rate.

Ninety-five per cent of the offspring were produced by the fresh spermatozoa when mixtures of fresh and aged spermatozoa were inseminated (Wf $\mathrm{Ba}$ or $\mathrm{Wa} \mathrm{Bf})$. Litter size and conception rate were unaffected by the age of the spermatozoa. Therefore, differential prenatal losses are unlikely to account for the differences in the ratios of offspring. Since immotile spermatozoa and inert particles are rapidly transported to the oviducts, it seems unlikely that aged and fresh spermatozoa are transported differentially to the oviducts. Therefore the 95:5 ratio of offspring is not a reflection of the number of spermatozoa at the site of fertilization.

Rabbit spermatozoa require $6 \mathrm{hr}$ for capacitation, which is necessary before they establish contact with the eggs and penetrate the zona pellucida (Austin, 1951; Chang, 1951; Bedford, 1967). In this study, $10 \mathrm{hr}$ elapsed from insemination to ovulation which is more than adequate for capacitation. Possible differences in speed of capacitation between breeds of bucks do not explain the ratios of offspring produced when fresh and aged spermatozoa were mixed (Wf $\mathrm{Ba}$ and $\mathrm{Wa} \mathrm{Bf}$ ) because the ratios were unaffected by breed.

Assuming equal numbers of both types of spermatozoa are transported to the site of fertilization, the differences in ratios might be due to the faster penetration of the eggs by the fresh spermatozoa. Determination of which spermatozoon fertilizes an egg does not appear to be a random process. 
Spermatozoa aged during storage fertilize a significantly smaller proportion of eggs than fresh spermatozoa when they compete directly. This aberrance is apparently not due to lack of fertilizing ability, embryonic losses, failure of capacitation or lack of transport on the part of the aged spermatozoa.

Thanks are due to Dr G. Polge for reading the manuscript and for his valuable editorial comments. Mr R. Marsh took care of the animals.

\section{REFERENCES}

Austin, C. R. (1951) Observations on the penetration of sperm into the mammalian egg. Aust. $\mathcal{F}$. sci. Res. 4, 581.

BeATty, R. A. (1960) Fertility of mixed semen from different rabbits. 7. Reprod. Fert. 1, 52.

BEDFORD, J. M. (1967) The importance of capacitation for establishing contact between eggs and sperm in the rabbit. F. Reprod. Fert. 13, 365.

Chang, M. C. (1951) Fertilizing capacity of spermatozoa deposited into the fallopian tubes. Nature, Lond. 168, 697.

EDWARDS, R. G. (1955) Selective fertilization following the use of sperm mixtures in the mouse. Nature, Lond. 175, 215.

Mattner, P. E. \& Braden, A. W. H. (1963) Spermatozoa in the genital tract of the ewe. 1. Rapidity of transport. Aust. F. biol. Sci. 16, 473.

VanDemark, N. L. \& Moeller, A. N. (1951) Speed of spermatozoan transport in reproductive tract of estrous cow. Am. F. Physiol. 165, 674 .

Warren, D. G. \& Kilpatrick, L. (1929) Fertilization in the domestic fowl. Poultry Sci. 8, 237. 